\section{STANDARDS OF CLEFT LIP AND PALATE CARE IMPROVED}

A study published in this issue of the $B D J$ has found that the reorganisation of NHS services for children in the UK with cleft lip and palate has improved standards of care. ${ }^{1}$ It has also led to a coordinated approach to national cleft research that has the potential to improve health and treatment worldwide.

The study, by researchers at the University of Bristol led by Professor Jonathan Sandy, found that the audit has informed the process of centralisation and a research strategy and infrastructure have been developed and embedded in the emerging clinical networks.

Around 1,000 children are born in the UK every year with a cleft lip and/or palate that requires treatment. However, until recently, the service was spread across many centres and few clinicians were engaged in audit or research projects.

Over the past 15 years there has been significant reorganisation and centralisation of UK cleft services, with the reduction of the 57 centres operating on these children in 1998 down to 11 centres or managed clinical networks in 2011.
The researchers found that not only are improvements in standards of care becoming evident, but important parallel developments initially in multidisciplinary audit, and latterly in research, have been initiated through this reconfiguration.

'Centralisation has not only raised the profile of this relatively small care group, but also enabled a UK-wide coordinated approach to research into cleft lip and palate, said Professor Sandy. 'This process illustrates how NHS services can provide a platform for national research that has the potential to improve health worldwide.'

1. Sandy J, Rumsey N, Persson M et al. Using service rationalisation to build a research network: lessons from the centralisation of UK services for children with cleft lip and palate. Br Dent J 2012; 212: 553-555.

\title{
ELECTIONS TO THE PRINCIPAL EXECUTIVE COMMITTEE 2012 - NOTICE OF BY-ELECTION IN NORTH WEST REGION
}

Elections to the British Dental Association's (BDA's) new Principal Executive Committee (PEC) were completed in May, except for the North West region, where no candidate was nominated.

Nominations for the by-election in the North West region are now invited, and completed nomination forms must be returned by $12 \mathrm{pm}$ on Wednesday 11 July 2012. Further information on the election, including a downloadable nomination form, is available on the BDA website at www.bda.org/pec. If you want a hard copy election pack sent to you, contact Stephen Skelton by emailing your request to s.skelton@bda.org or telephoning 02075634141 .

\section{The Principal Executive Committee (PEC)}

The PEC has overall responsibility for the control and direction of the policy and affairs of the Association, and its members are the Directors of the Association.

There are 12 members of the PEC apart from the senior officers such as the Chair, and it is anticipated that each will have a fair share of overall responsibilities. Typically this will require:

- Attendance at all meetings of the PEC - usually four a year, but maybe more to begin with

- Attendance at own country council meetings

- Attendance at UK Council meetings

- Sitting on 1-2 sub committees/issue specific forums
- Attendance at general meetings of the Association

- Attendance at the annual meeting of the Scrutiny Committee and accountability review.

It is anticipated that the approximate time commitment for an ordinary PEC member will be 20 days per year, with an annual remuneration of $£ 15,000$.

\section{Term of office}

This shall be until December 2014, with the entitlement to stand for a further three year term.

\section{Induction, support and training}

Membership of the PEC will carry significant organisational and legal responsibilities. There will therefore be a thorough induction programme for those elected, and ongoing training. Members will also have 'civil service' advice and support from the Chief Executive and his staff.
DIARY

British Dental Bleaching Society Conference 2012

Date: 26 July 2012

Venue: Royal College of Surgeons, London

Telephone: 02072677070

Email: info@bdbs.co.uk

www.bdbs.co.uk

100th FDI Annual World

Dental Congress

Date: 29 August - 1 September 2012

Location: Hong Kong

www.fdicongress.org

Migraine Awareness Week: seminars by Dr Pav Khaira

Date: 2-8 September 2012

www.s4sdental.com

17th World Congress on Dental Traumatology

Science and Art: Overcoming the Limits of Knowledge

Date: 10-22 September 2012

Venue: Rio de Janeiro, Brazil

www.iadt-dentaltrauma.org

www.sbtd.org.br

\section{Optimising Outcomes}

in Restorative Dentistry

Date: 20 September 2012

Venue: Symposium Hall of the

College, The Royal College of

Surgeons of Edinburgh

Email:h.anderson@rcsed.ac.uk

Telephone: 01316689239

https://ubis.rcsed.ac.uk/courses/

coursedetails.aspx?diaryld $=1027$

Current Concepts in Hard Tissue Grafting for Accelerated Implant Reconstruction

Date: 21-22 September 2012

Venue: Spectrumsmiles, Jersey

Telephone: 01534743849

Email: info@spectrumsmiles.co.uk

www.courses4implants.com

\section{DDU-Eastman}

Dento-Legal Conference

Date: 28 September 2012

Location: London

Email: edi-cpd@ucl.ac.uk

www.the-ddu.com

BDTA Dental Showcase

Date: 4-6 October 2012

Venue: ExCeL London

www.dentalshowcase.com 